6. Kalmuchyn- Dranchuk, T. (2005) M. Kolessa's pianoforte work in the context of performance explication problem. Bulletin of the Precarpathian University. Art studies, Vol. VIII, 73-80 [in Ukrainian].

7. Kyyanovska, L. (2009). Sociocultural paradigm of Lviv school of composition. NTSh Notes: Proceedings of the musicological committee, Vol. CCLIII, 125-134 [in Ukrainian].

8. Kyyanovska, L. (2000). Style evolution of Galician musical culture of the 19th -20 th centuries. Ternopil: Aston, 339 [in Ukrainian].

9. Krushelnytska, M. (1994) Style features of performing pianoforte works of M. Kolessa. The Ukrainian pianoforte music and performing. Materials of the 3rd Conference, 51-53[in Ukrainian].

10. Lantsuta, L. (1996). The Ukrainian neo-romantic pianoforte sonata. The Works of Music Studies Commission, Vol. CCXXXII, 165-179 [in Ukrainian].

11. Mulyar, P. (2009). The style of the work and performing interpretation in terms of interaction and classical pianoforte art: Candidate's tesis. Odesa: ONMA named after A. V. Nezhdanova [in Ukrainian].

12. Nikolayeva, L. (1983). Folk elements in the pianoforte works of M. Kolessa [to the 80th anniversary of the birth]. mag.»Folk Art and Ethnography», No.6, 28-34 [in Ukrainian].

13. Stetsyuk, R. (1974). Viktor Kosenko. Kyiv: Musical Ukraine [in Ukrainian].

14. Khil, O. (2015). The theme of childhood, youth as a genre factor of typology of pianoforte concert in domestic instrumental music of the 20th century: dis. PHD. Odesa: ONMA named after A. V. Nezhdanova [in Ukrainian].

Стаття надійила до редакції 19.04.2017

УДК $78.083 / 78.03+781 / 784.3$

\author{
Лю Юйтен \\ здобувач кафедри історії музики \\ та музичної етнографіі \\ ОНМА ім. А. В. Нежданової \\ odma_n@ukr.net

\section{ЖАНРОВО-СТИЛЬОВА ДІАЛОГІЧНІСТЬ КАМЕРНО-ВОКАЛЬНОЇ ТВОРЧОСТІ ЯК ПРЕДМЕТ МУЗИКОЗНАВЧОГО ДИСКУРСУ}

Мета статті полягає у визначенні та розмежуванні жанрових та стильових критеріїв вивчення камерно-вокальної творчості, що сформовані у музикознавчих роботах останніх років, водночас у виявленні вихідної єдності - образно-естетичної інтегративності жанрово-стильової форми камерно-вокальної музики. Методологія роботи обумовлена 
діалогічним естетико-літературознавчим та музикознавчим підходами, орієнтована на виявлення іманентних властивостей камерно-вокального твору як художньо-виразової єдності жанрових передумов та стильових чинників, що реалізується специфічним композиційним шліхом. Наукова новизна статті визначається широтою та систематичністю представлення існуючих дискурсивних оцінок камерно-вокальної творчості та створенням на їх основі нового дослідницького концепту, що підсилює естетичні та семіологічні тенденції музикознавчого аналізу, також вказує на їх методичну спорідненість. Висновки. Доводиться, що жканрова природа камерно-вокальної музики заснована на єдності епічних, драматичних та ліричних художньо-мовленнєвих ознак, а визначальними стильовими чинниками виступають історичні композиційно-стилістичні канони та принципи авторських стилів, що утворюють відкриту площину відкритого інтертекстуального музичного самодіалогу.

Ключові слова: камерно-вокальна творчість, жсанрові та стильові критерії, інтегративність жанрово-стильової форми, музикознавчий дискурс, естетичні та семіологічні тенденції, художньо-мовленнєві ознаки, інтертекстуальний музичний самоділог.

Liu Yuthen, applicant of the Department of Music History and musical ethnography of Odessa national $A$. $V$. Nezhdanova academy of music

The genre and style dialogicality of the chamber-vocal art as the subject of the musicologycal discourse

The purpose of the article is to determine and distinguish genre and stylistic criteria for the study of chamber-vocal creativity, which have been formed in musicology works of recent years, while at the same time discovering the original unity of figurative and aesthetic integrity of the genre-stylistic form of chamber-vocal music. Methodology of work is conditioned by dialogical aesthetic-literary and musicology approaches, focused on revealing the immanent properties of chamber-vocal composition as an artistic and expressive unity of genre prerequisites and stylistic factors implemented by a specific compositional way. The scientific novelty of the article is determined by the width and systematic presentation of existing discursive assessments of chamber vocal creativity and the creation of a new research concept that reinforces the aesthetic and semiological tendencies of musicological analysis, also points to their methodological affinities. Conclusions. It is proved that the genre nature of chamber-vocal music is based on the unity of epic, dramatic and lyrical artistic-speech features, and the historical compositional-stylistic canons and principles of author's styles, which form the open plane of the open intertextual musical self-dialogue, serve as determining stylistic factors.

Keywords: chamber-vocal creativity, genre and style criteria, integrity of genre-style form, musical discourse, aesthetic and semiotic tendencies, artistic-speech signs, introspection musical self-dialogue. 
Лю Юйтен, соискатель кафедры истории музыки и музыкальной этнографии ОНМА им. А. В. Неждановой

Жанрово-стилевая диалогичность камерно-вокального творчества как предмет музыковедческого дискурса

Цель статьи заключается в определении и разграничении жканровых и стилевых критериев изучения камерно-вокального творчества, сформированных в музыковедческих работах последних лет, в то же время в выявлении исходного единства образно-эстетической интегративности жанрово-стилевой формы камерно-вокальной музыки. Методология работы обусловлена диалогическим эстетико-литературоведческим и музыковедческим подходами, ориентированными на выявление имманентных свойств камерно-вокального произведения как художественно-выразительного единства жанровых предпосылок и стилевых факторов, которое реализуется специфическим композиционным путем. Научная новизна статьи определяется широтой и систематичностью представления существующих дискурсивных оценок камерно-вокального творчества и созданием на их основе нового исследовательского кониепта, усиливает эстетические и семиологические тенденции музыковедческого анализа, также указывает на их методическое родство. Выводы. Доказывается, что жсанровая природа камерно-вокальной музыки основана на единстве эпических, драматических и лирических художественно-речевых признаков, а определяющими стилевыми факторами выступают исторические композиционно-стилистические каноны и принципы авторских стилей, образующие открытую плоскость открытого интертекстуального музыкального самодиалога.

Ключевые слова: камерно-вокальное творчество, жанровые и стилевые критерии, интегративность жканрово-стилевой формы, музыковедческий дискурс, эстетические и семиологические тенденции, художественно-речевые признаки, интертекстуальный музыкальный самодилог.

Актуальність. Глибина розуміння камерно-вокального твору прямо залежить від ступеня виявлення семантичної природи його жанрової форми, обумовленої його естетичною ідеєю. У той же час обговорення природи камерно-вокального жанру як системи логікосемантичних прототипів до виникнення низки питань.

Перше з них - питання про жанрову типологію або жанрові критерії; друге - питання про взаємодію жанру й стилю, вірніше обговорення жанру - стилю як парної категорії діалогічної побудови, що виражає найбільш ємно сутність внутрішньохудожнього діалогу; третє - питання про жанровий контекст як про всі ті зв’язки жанру, які не обмежені його конкретними композиційними структурами, але виникають у випадках міжжанрового діалогу та звертання до даного жанру з позиції інших композиційних форм. 
До поняття про жанровий контекст приєднують поняття стильового контексту. Ключ до його своєрідності дає взаємодія в долі будьякого стилю двох типів канонів або - словами М. Бахтіна - взаємодія авторитету та автора, загальновизнаних, загальноприйнятих стильових канонів і індивідуально-авторських, які в межах авторської творчості уточнюють, виокремлюють канони стилю в цілому, іноді суттєво обновляючи їх. Вивчення жанрово-стильових контекстів у їх взаємній корекції утворює четверте питання - про можливості еволюції стилю та жанру в їх координації. Це питання можна назвати історичним, тому що воно обов'язково вимагає порівняльно-історичного аналізу музичних явищ; але його ж потрібно назвати й культурологічним: порівняння різних за жанровою природою музичних явищ, які, проте, мають якісь подібні ознаки, або порівняння аналогічних жанрово-стильових рішень в силу їх історичного розділення (віддаленості), що набувають принципово різного образно-смислового характеру - неможливо без співвіднесеності з контекстом культури як і з найбільш загальним жанровим контекстом.

Мета статті полягає у визначенні та розмежуванні жанрових та стильових критеріїв вивчення камерно-вокальної творчості, що сформовані у музикознавчих роботах останніх років, водночас у виявленні вихідної єдності - образно-естетичної інтегративності жанрово-стильової форми камерно-вокальної музики.

Основний зміст роботи. Як культурний феномен, музичний жанр припускає історичне походження і певні умови побутування, тобто постійну взаємодію традиційного, канонічного, інваріантного й новаторського, евристичного, мобільного, що, в остаточному підсумку, забезпечує довгочасне існування жанру, рівною мірою потребує і самоповторень, і руху вперед. М. Бахтін у зв'язку з цим відзначав, що жанр «вічно той же, вічно новий», розглядав функціонування художнього жанру в якості «пам'яті» культури [1-3].

Таким чином, первинні жанри - історична, і логічна предтеча професійної композиторської творчості. У презентованій вторинній музиці вплив ускладнюється, обирає інші форми, але мета його залишається тією самою: спочатку індивідуальне почуття через твір музичного мистецтва переростає в суспільне або узагальнюється, виражаючи ту ж потребу катарсису, яка існувала й у правитоках сучасного мистецтва. Взаємодія первинних і вторинних жанрів, тісний взаємозв'язок між «повсякденною» та презентованою музикою один з важливих законів розвитку музичної культури. 
Музичний твір не може бути естетично дієвим, якщо його мова позбавлена коріння у повсякденному музичному мисленні, у фольклорній і релігійній культурі: властне «мова» у цьому випадку й не виникне... Образно-змістовна визначеність твору завжди пов'язана 3 конкретним інтонаційно-ритмічним виглядом теми. Художньо значима тема не може виникнути в уяві композитора поза музичножанровими традиціями культури. Типи жанрової характеристичності музики, такі як речитативність, пісенність, танцювальність, склалися саме в результаті застосування музики у побуті, відображуючи історично успішний досвід повсякденного музикування.

Жанрове позначення - свого роду сигнал для слухачів, що активізує накопичені ними асоціації й певною мірою визначає спрямованість їх сприйняття. Це й пояснює важливість вибору автором того або іншого жанрового матеріалу (прототипу) для свого твору. В основі слухацької інтерпретації лежить таке об'єктивне начало як слуховий досвід культури, історично визначений, що обумовлює досвід музичного сприйняття, нарешті жанрові умови, установки, обстановка сприйняття музики, хоча слухач мимоволі домислює емоційний зміст сприйнятого музичного явища, доповнюючи, перетворюючи його за допомогою власної уяви. Якщо музичний матеріал здатний дійти до широкої аудиторії, то значить, що він містить асоціативні зв'язки, що виробилися в процесі тривалого суспільного відбору та знайшли первинне вираження в жанрах побутової музики.

Щодо цього однією з останніх музикознавчих робіт, що актуалізують проблему жанру в напрямку, що цікавить нас, у зв'язку з явищами діалогу, семантики, з вивченням музики як особливого типу мислення в цілому, є дослідження М. Бонфельда [5]. Автор відзначає, що категорія жанру переплітається з поняттями роду, виду і стилю, може видаватися довільною, не аргументованою. Він справедливо пов'язує посилення інтересу до цієї категорії з іменем М. Бахтіна, що саме собою веде у бік вивчення мнемонічних функцій жанру й діалогічного підходу до нього. Жанри важливі як носії певного досвіду і дозволяють зрозуміти художній досвід як переважно смисловий. Тому «пам'ять жанру» — це пам'ять і про форму, і про смисл, i «воля» жанру є більш владною, ніж авторська - як воля традиції.

М. Бонфельд підсумовує основні концепції жанру у вітчизняному музикознавстві, однак не включає в них текстологічний підхід, який найбільшою мірою, на наш погляд, сполучений з культурологічними критеріями. Однак без останніх важко виявити властивості первинно- 
го жанру, для якого очевидними й корінними, як зауважує сам Бонфельд, є зв’язки з позамузичною ситуацією (тоді як вторинні жанри визначаються автономними інтрамузичними процесами, хоча тісно пов'язані з семантикою первинних). Бонфельд розбудовує категорії первинності та вторинності жанрів у музиці у зв’язку з історичним досвідом культури. Він вводить також поняття про жанрову семантику «субзнакового шару музичної мови» як об’єктивного фактора: така семантика виявляється в сприйнятті, але одночасно незалежна від нього $[5,152]$. На наш погляд, це положення роботи Бонфельда наближено до уяви про інтертекстуальність (інтертекстові формули), яке формується в дослідженні М. Арановського [1].

Жанрова семантика, яка впізнається в різних стильових контекстах і забезпечує смислову визначеність музики, може розглядатися як інтертекстуальний феномен. Відновлення семантики субзнакового шару музичної мови відбувається як інтонаційна криза, художнє відкриття, парадоксальний синтез, завжди пов'язані з яскравою взаємодією ознак різних «художніх дійсностей». Саме з даним відновленням пов'язаний, за думкою М. Бонфельда, діалог у музиці, якщо розглядати поняття про діалог як універсальне та присутнє в будьякому мовному контексті. Автор справедливо відзначає відсутність методичної цілісності в музикознавчих роботах, звернених до поняття діалогу. Він вважає, що причиною цього є, у тому числі, недостатня увага до жанрового змісту музичного твору.

Поняття про музичний жанр невіддільне від поняття про музичний стиль, обидва поняття потребують взаємного пояснення та уточнення, є необхідними в процесі пізнання рис спільності і відмінності існуючих систем музичного мислення. У свою чергу музичне мислення у його жанровій зумовленості передбачає взаємодію епічних, драматичних та ліричних чинників у створенні музичної образності, причому певний чинник стає переважаючим, таким, що найближче підводить до естетичної природи жанрової форми. У сфері камерновокальної музики домінуючим естетичним фактором стає ліричний, що розкривається у значному художньо-змістовому обсязі, від узагальнююче-смислового стильового рівня до конкретних музичностилістичних знакових прийомів.

Інтегративність жанрово-стильової форми, яка виявляється у камерно-вокальній музиці, зумовлена взаємодією єдиних естетичних та семіологічних тенденцій музичної творчості, що на рівні художнно-мовленнєвих ознак може розглядатися як інтертекстуальний музичний самоділог. 
Про шляхи виявлення даного діалогу в жанровій формі камерно-вокальної творчості свідчить концепція роботи О. Лісової, у якій виявляються такі стилістичні показники, як деталізованість і «наскрізна» процесуальність музичного тематизму, його особлива лаконізація, що приводить до виникнення мікротематизму.

Зокрема до змісту мікротеми потрапляють прийоми вокальномовного «подиху» - «прямої мови» виконавця-вокаліста, що зумовлюють особливу експресію камерно-вокального співу. Дана лаконізація мовних засобів поєднана з обмеженням осіб виконавців, аж до монологізації зовнішньої форми камерно-вокального твору, при відносній статиці поведінки головної «діючої особи», що дозволяє зосереджено прослідковувати динаміку ії міркувань і переживань. Ці риси камернізації вокального виконавства О. Лісова пов'язує з домінуючою роллю ліричного начала [7].

Дослідниці вдається відкрити явище жанрової інтерференції як умову еволюції камерної вокальної музики, що полягає в накладенні ознак однієї жанрової форми на іншу, наприклад, опери «малої форми» на камерно-вокальний цикл, «з наступною зміною кожної, але й зі збереженням вихідних ознак», тобто свого роду жанрово-стилістичний «білінгвізм» камерної вокальної музики.

Зокрема О. Лісова відзначає, що музична інтерференція припускає спільну реалізацію різних жанрових завдань, тобто жанрово-мовний білінгвізм, сполучає й загальні естетичні передумови, і зовнішні предметно-структурні умови, і внутрішні композиційно-стилістичні правила, властивості художніх жанрових форм.

Разом з тим і в повсякденному мовному середовищі, і в художній творчості інтерференція виявляється не стільки причиною, скільки наслідком виконання більш загального діяльнісного завдання - цілісної програми дії, творчого зусилля, тобто вона програмується смисловим завданням, яке в мистецтві має естетичну спрямованість, отже програмується жанрово-естетичними тенденціями художньої творчості.

У музиці ці тенденції - родова та видова естетична програма жанру - обумовлені участю позамузичних компонентів, з яких головним $€$ словесний ряд, поетично оформлене слово, що включене у розгортання специфічно музичної композиції, тобто програмністю в традиційному вузькому значенні цього поняття.

Отже для камерної вокальної музики роль слова як програмного компонента виявляється вирішальною, хоча й розкривається на різ- 
них рівнях музичної форми, у різних напрямах і співвідношеннях з музично-інтонаційним змістом. Так чи інакше, визнаючи наявність двох основних жанрових форм у камерній вокальній музиці в її русі від дев'ятнадцятого століття до двадцятого й двадцять першого, а саме, камерно-вокального циклу та камерної опери, дослідниця пропонує вважати загальною естетичною програмою жанру в галузі камерної вокальної музики саме відношення до слова та літературнопоетичного першоджерела.

Це відношення вона пропонує розглядати як передумову реалізації програмних установок камерно-вокального твору та за їх допомогою явища інтерференції в його музично-творчій своєрідності.

О. Лісова підкреслює, що, як і інші смислові естетичні феномени, інтерференція отримує найбільш «чисте» і повне вираження саме в мистецтві, яке об'єктивує, упредметнює психологічні процеси, що відбуваються у свідомості суб’єкта творчості. Крім того, вона звертає увагу на те, що специфікація музично-творчого процесу відбувається на основі жанру як головного представника традиції та носія комунікативних властивостей музики. Таким чином, увага до явища інтерференції припускає вивчення способів взаємодії зі словом, прийнятих у камерно-вокальній творчості, в їх залежності від сталих жанрових тенденцій творчості та в програмній дієвості для цих форм. Одночасно відзначається, що участь слова в музичній творчості вже є спонуканням до інтерферентного процесу, оскільки буквально представляє білінгвізм - словесно-музичну двомовність - жанру [7, 13-14].

У даній роботі широко обгрунтовується і явище ліричного - як поглиблення особистісного начала, піднесення та ідеалізації, які найбільш безпосередньо втілюються в сфері камерного вокального циклу та ведуть до відокремлення камерного жанру як авторизованого, автобіографічного, навіть «сповідального», до свободи вибору й трактування композиційних і стильових прототипів у камерній музиці. Це дозволяє поглиблювати уявлення про специфічні можливості музичної мови, про особливе значення для відтворення ліричної музичної семантики вокального інтонування - «живого» одухотвореного звучання людського голосу як виявленого у звуці унікального психологічного малюнка особистості [7, 167, 173].

Спорідненими, але поглибленими на основі теорії діалогу, виявляються дослідницькі позиції О. Філатової, що вивчає діалог музики зі словом, музичної форми зі словесно-поетичною як «усе більшу еман- 
сипацію музичних значень шляхом виявлення глибинного смислового змісту поетичного тексту». Дослідниця намагається визначити передумови нової виконавської свободи в інтерпретації «віршів 3 музикою», яка пояснюється особливими діалогічними якостями даної жанрової форми, у тому числі зближенням позицій, співавторством композитора і поета, що також стає атрибутивною рисою камерновокальної творчості [8, 183-184].

О. Філатова відзначає, що спільні властивості діалогу, які розбудовує камерно-вокальна музика у іiї жанрових різновидах, формуються на основі специфічних властивостей, що виникають із функціональних відмінностей («розбіжності» у діалозі) і функціонального зближення («згоди» у діалозі) виконавця інструментальної партії та вокаліста. Її словами, «у вокальній партії здійснюється зв'язок зі словом, що надає образному змісту сюжетності, а музичному інтонуванню - семантичної конкретизації. Лінеарність викладу вокальної мелодії підкреслює часовий характер музичнотворчого процесу». Фортепіанна ж партія «забезпечує образну узагальненість, драматургічну цілісність та континуальність у часовому становленні форми твору і єдність, континуумність просторової вертикалі музичного тексту. Їй властиві також спрямованість до свободи асоціативно-художнього ряду, семантична незалежність (від слова або інших позамузичних компонентів) фактурних, тембрових, інших просторових координат у музиці... Тому саме вона диктує «почуття стилю» як фактора організації художнього цілого» [8, 186-187].

Серед основних положень роботи О. Філатової методичної важливості набувають саме ті, які звернені до проблеми жанрової диференціації музичного мистецтва.

По-перше, автор вказує на той рух від виконавської прагматики до синтаксису форми, яким пояснюється розмежування так званих жанрово-родових ознак у музиці, що є іiї жанрово-естетичними темами - епічною, драматичною та ліричною. За ії словами, хоча музику, як і поезію, відносять до ліричного роду мистецтва (пов'язуючи з емоційно-психологічним виявленням людини), вона досить адекватно відтворює риси епосу й драми завдяки особливостям музичної композиції.

Дослідниця звертається до роботи М. Бонфельда у зв'язку з тим, що він знаходить близькість музичної прагматики до вчення про роди мистецтва, оскільки центральне положення в них займає проблема 
авторського «Я». Крім того, Бонфельд справедливо зауважує, що родові членування в музиці дотепер не стали предметом спеціального вивчення, імовірно, тому, що залишається неясним, яку саме сторону музичного твору вони представляють (див.: [5]).

Продовжуючи цей дискусійний напрям в обговоренні жанрової природи музики, О. Філатова вказує на той факт, що багато авторів наполягають на приналежності музики тільки до ліричного роду мистецтва, хоча вони ж знаходять у музиці й драматичні, й епічні ефекти, але поверх ліричної природи. Виходячи з думки М. Кагана про те, що поетична лірика стала «музикою в літературі» або «літературою, що прийняла на себе закони музики», Філатова намічає два кола питань.

Перше - про можливі критерії епічного, драматичного й ліричного в музиці, причому як з боку загальнохудожніх ознак, так і з боку музично-специфічних прийомів.

Друге коло питань звернене до класифікації жанрових форм музики як родових, яке обертається спробою створення свого роду «жанрової історії» музики. Вона особливо підкреслює ту обставину, що в більшості випадків музичне формоутворення історично одночасно ініціювалося законами епосу, драми й лірики, навіть при визнанні одного з них провідним [8, 35-36].

Крім того, О. Філатова звертає увагу на те, що історично вихідні епічні жанрові форми мають у якості опорних первинних (генетичних) саме виконавські ознаки - хоча б у їх найбільш загальному вигляді; такими є хорова і досить довгий час акапельна природа музичного епосу, інструментальна й змішана «театралізована» природа драматичної сфери в музиці, нарешті сольна й сольно-ансамблева природа ліричного, буквально пов’язана з камернізацією.

Таким чином, їй вдається виявити, що у своєму історичному розвитку музика йшла від загального колективного, анонімного висловлення до окремого особистісного, авторського. Музична свідомість розбудовувалася шляхом усе більшої диференціації музичних уявлень та мовних засобів. У певному відношенні це відповідає розвитку музичного звучання (у його вже не тільки часових, але й просторовофактурних параметрах) від монодичного до складного-поліфонічного.

Дуже ємною постає думка О. Філатової про те, що семантичне багатоголосся музики стає можливим тоді, коли в окремого голосу з'являються самостійні права. У такому випадку розвиток ліричного начала в музиці як особливого жанрово-семантичного типу, пов’язаного з індивідуалізацією процесу музичної творчості, слід ви- 
знати можливим тільки у вторинній жанровій системі, внаслідок чого останню можна вважати переважно ліричною [8, 37-39].

Узагальнюючи найбільш рельєфні тенденції музикознавчого осмислення категорії жанру у контексті камерно-вокальної музики, відзначимо, що надзвичайно продуктивним стає уявлення про особистість музиканта як окрему та самоцінну, що має право на власний голос у прямому те переносному, образно-метафоричному сенсі.

Така думка обумовлена авторським осмисленням природи музики у зв'язку з її новим жанрово-типовим устремлінням до лірики. Навіть, здавалося б, великі монументальні епічні, оперно-ораторіальні або ораторіально-симфонічні форми в музиці у процесі їх слухацького відтворення, культурного побутування розкриваються як акти особистісного творчого «висловлення» режисера-постановника, диригента, окремих виконавців і т. д.

Стаючи частиною романтичної та постромантичної музичної свідомості, висловлена в камерно-вокальній музиці індивідуально-авторська свідомість, композиторська та виконавська свідомість виражає нові закономірності впливу музики й спрямована до здійснення музики як міжособистісного діалогу, інтимного спілкування, особистісного одкровення і т. д. У такий спосіб актуалізується й поняття про ліричне в його значенні для музично-стильового мислення.

Однак критерії вивчення ліричного в музиці усе ще потребують спеціального обговорення, а також - спеціалізованого підходу у зв'язку з окремими жанровими формами. Саме тому можливо говорити про розгорнуту жанрову дефініцію ліричного в музиці у зв'язку з камерними вокальними формами. Зокрема О. Філатова зауважує, що «інтерес до останніх підсилюється обставиною, що саме дані форми пропонують «зустріч» двох визнаних родів ліричного в мистецтві музики і поезії - при досить яскраво вираженій авторизованості кожного з них» $[8,39]$.

Отже музикознавчий дискурс, що розгортається в дослідженнях останніх двох десятиліть у зв'язку з вивченням камерно-вокальної творчості, створює достатні методологічні підстави для виділення жанрово-стильового підходу, спонукає до його діалогічного поглиблення.

Наукова новизна статті визначається широтою та систематичністю представлення існуючих дискурсивних оцінок камерно-вокальної творчості та створенням на їх основі нового дослідницького концепту, що підсилює естетичні та семіологічні тенденції музикознавчого аналізу, також вказує на їх методичну спорідненість. 
Висновки дозволяють стверджувати, що жанрова природа камерно-вокальної музики заснована на єдності епічних, драматичних та ліричних художньо-мовленнєвих ознак з виділенням ліричного начала як інтегративного, а визначальними стильовими чинниками виступають історичні композиційно-стилістичні канони та принципи авторських стилів, що утворюють відкриту площину інтертекстуального музичного самодіалогу.

\section{СПИСОК ЛІТЕРАТУРИ}

1. Арановский М. Музыкальный текст. Структура и свойства. М.: Композитор, 1998. $341 \mathrm{c.}$

2. Бахтин М. Эпос и роман. Бахтин М. Вопросы литературы и эстетики. Исследования разных лет. М.: Художественная литература, 1975. С. 447483.

3. Бахтин М. Автор и герой в эстетической деятельности. Бахтин М. Эстетика словесного творчества. М.: Искусство, 1986. С. 9-191.

4. Бахтин М. Проблема речевых жанров. Бахтин М. Эстетика словесного творчества. М.: Искусство, 1986. С. 381-393.

5. Бонфельд М. Музыка. Язык. Речь. Мышление. Опыт системного анализа музыкального искусства: монография. СПб.: Композитор-СанктПетербург, 2009. 648 с.

6. Васина-Гроссман В. Музыка и поэтическое слово. М.: Музыка, 1972. Ч. 1. Ритмика. $150 \mathrm{c}$.

7. Лисовая О. Программность как жанровая парадигма камерной вокальной музыки: к проблеме исполнительского: дис. ... канд. искусств: 17.00.03 / ОНМА им. А. В. Неждановой. Одесса, 2009. 199 с.

8. Филатова О. Жанровый генезис исполнительского диалога в музыке (на материале камерно-вокального творчества): дис. ... канд. искусств.: 17.00.03 / ОНМА им. А. В. Неждановой. Одесса, 2005. 214 с.

\section{REFERENCES}

1. Aranovsky, M. (1998). Music text. Structure and properties. M.: Composer [in Russian].

2. Bakhtin, M. (1975). Epos and the novel // M. Bakhtin. Questions of literature and aesthetics. Studies of different years. M.: Fiction. P. 447-483 [in Russian]..

3. Bakhtin, M. (1986). Author and hero in aesthetic activity // M. Bakhtin. Aesthetics of verbal creativity. M.: Art, P. 9-191[in Russian].

4. Bakhtin, M. (1986). The Problem of Speech Genres // M. Bakhtin. Aesthetics of verbal creativity. M.: Art. P. 381-393 [in Russian].

5. Bonfeld, M. (2009). Music. The language Speech Thinking Experience in system analysis of musical art. Monograph. St. Petersburg: Composer - St. Petersburg [in Russian]. 
6. Vasina-Grossman, V. (1972). Music and poetic word. M.: Music, Part 1. Rhythmics. [in Russian].

7. Lisovaya, O. (2009). Programming as a genre paradigm of chamber vocal music: the problem of performing: Candidate's thesis: 17.00.03 / ONMA them. A. V. Nezhdanova. Odessa [in Russian].

8. Filatova, O. (2005). Genre genesis of performing dialogue in music (on the material of chamber vocal creativity): Candidate's thesis: 17.00.03 / ONMA them. A. V. Nezhdanova. Odessa [in Russian].

Стаття надійшла до редакції 26.04.2017

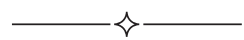

УДК 78.01/.071.1+781.9/.68/.61+786.2

\author{
Ма Сінсін \\ здобувач кафедри історії музики \\ та музичної етнографіі \\ ОНМА ім. А. В. Нежданової \\ onlyfly_world@ukr.net

\section{ОРАТОРІАЛЬНІСТЬ ЯК СТИЛІСТИЧНИЙ ВИМІР ТА СЕМАНТИЧНА ДОМІНАНТА ФОРТЕПІАННОГО ВИКОНАВСТВА}

\begin{abstract}
Мета статті полягає у визначенні ораторіальних якостей музичновиконавської форми як важливого чинника розвитку фортепіанно-виконавського стилю. Методологія роботи зумовлена поєднанням узагальнюючого теоретико-гуманітарного, зокрема типологічного ноетичного, та конкретно-емпіричного, а саме аналітичного музикознавчого, підходів. Наукова новизна дослідження визначається вивченням ораторіальності як безпосереднього рупору художньої авторської ідеї, що поєднує інтенціональні плани композиторської свідомості та виконавського інтерпретативного мислення, підтвердженням даної концепції на прикладі фортепіанного методу С. Рахманінова. Висновки роботи дозволяють стверджувати, що квалітативними ознаками ораторіальності, котрі виявляють ї̈ образно-смислову виконавсько-інтерпретативну широту, $\epsilon$ : піднесеність, форсована значущість, ефект об'єктивності художнього вчинку, водночас підвищена загальна сугестивність, авторитарність, укрупненість почуття, філософічність - інтелектуалізація.

Ключові слова: ораторіальність, фортепіанно-виконавський стиль, інтерпретативне мислення, квалітативні ознаки ораторіальності, фортепіанний метод С. Рахманінова.
\end{abstract}

